\title{
Service Quality Analysis of Banks in Rajasthan Post Financial Inclusion Program
}

\author{
SHAILJA KHANDURI \\ Department of Economics, Doon Business School \\ Mi-122, Selaqui, Dehradun, Uttarakhand-248007, INDIA
}

\begin{abstract}
This study applies SERVQUAL analysis to measure the service quality offered by Indian banking sector in the Indian state of Rajasthan. This study was performed 5 years after the launch of national mission for financial inclusion by Indian government. Both the public and private sector banks were incorporated in the study. Respondents are mostly from the urban background spread over various cities in Rajasthan. The dimensions studied are tangibility, reliability, responsiveness, assurance and empathy. The average SERVQUAL score was found to be -0.189 and the results reveal about $95.22 \%$ customers' expectations were met. The empathy factor satisfying customers' expectations (99.28\%) shows the tremendous quality of personal handling in Indian banks service sector, while the lowest score on the reliability factor $(89.63 \%)$ gives an idea of customer's concerns regarding reliability of services in Indian banking sector. Overall, the present study finds that Indian urban banks average performance vis-à-vis the five service quality dimensions is quite satisfactory.
\end{abstract}

Key-Words: - PMJDY, Financial inclusion, SERVQUAL, Banking, Service, Quality

Received: August 4, 2020. Revised: January 24, 2021. Accepted: January 26, 2021.

Published: February 1, 2021.

\section{Introduction}

In August 2014, Indian government launched financial inclusion program in India, (Pradhan Mantri Jan Dhan Yojana, PMJDY) which offers universal banking services for every unbanked adult (National Mission for Financial Inclusion, NMFI) [1]. Financial inclusion of majority population is performed for sustainable economy and economic growth in developing nations [2-4]. Under PMJDY, various benefits are provided, such as; one basic savings account for unbanked person, zero minimum balance, interest earnings, RuPay debit card, INR 0.2 million for inadvertent indemnity cover, INR 30,000 life insurance cover, and an overdraft facility of up to INR 10,000. The PMJDY accounts could be opened at any bank branch. The success of PMJDY scheme could be gauged by the fact that at present (July'2020), there are about 399.5 million beneficiaries and an amount of INR $1,310,325$ million balance is deposited in beneficiary accounts. The PMJDY scheme also did employment generation as about 0.126 million Bank Mitras (agent or contractual employees) are hired for delivering branchless banking services in subservice areas like villages and small towns.

This massively successful financial inclusion exercise in the world's largest democracy needs to be studied in its entirety. The success of PMJDY scheme primarily depends on the service quality offered by the Indian banking sector. However, there is an existing research gap vis-à-vis rigorous quantitative analysis of the impact of PMJDY. This preliminary study applies SERVQUAL method analysis [5], to measure the service quality offered by Indian banking sector in the Indian state of Rajasthan. Respondents were customers of private and public segment banks from the urban background spread over various cities in Rajasthan, India. The dimensions studied are tangibility, reliability, responsiveness, assurance and empathy. As, there is a lack of studies in published literature where SERVQUAL instrument is used to assess the service quality of public and private sector banks in India vis-à-vis PMJDY, after a consequential period of launch, we believe that the work presented in the paper manuscript does indeed fill the void in published literature. Further, the present work would have a significant academic value as it would enhance the coherency and entirety of understanding of the service quality of Indian public and private banks. In addition, the study is also of practical value as it provides the associated bank managers to really comprehend the relationship between the present status of service quality efforts implemented by the banks and the perception that they evoke in the minds of their customers. 


\section{Service Quality Quantification}

The trust of bank customers is one of the most significant criteria for growth and sustainability for any banking firm, apart from non-performing loan ratio, ownership (private or government) and diversified monetary services [6-8]. However, it is quite challenging task for a bank to continuously remain as the preferred choice among the majority of its clients, as there would always be a difference of opinion between what the bank management perceives as the best service for its customers and the customers' own personal expectations. On one hand, banks try to draw new customers through attractive new schemes and innovative branding and marketing, and on the other, they try to keep their loyal customers engaged through continuous up gradation of their existing relationship with the bank. Therefore, there is an unvarying demand for investigating the usual and supposed excellence of produce and services by banks to augment profitability and sustaining their present customers. To attain and preserve aggressive lead, banks need to classify, appraise and evaluate their service quality in comparison to competing firms as banking sector is quite competitive and there are numerous banks operating at any place at the same time. Most of the banking operations are similar and digital technology advancement has brought the banking firms on an identical level playing field. Therefore, it is very important for any bank to provide the best personal services to its present customers and to attract the new ones. Having an understanding, empathetic, aware, assuring and responsible bank staff is what would eventually make a bank stand out from the competitors. Different methodologies for quantifying and assessing the firm's performance have been employed [9, 10]. Customer loyalty may also be measured by banks through assessment of customer satisfaction and it could then strive to perk up the class of services that may cause frustration among its loyal customers.

SERVQUAL instrument remains one of the most paramount and broadly implemented techniques for evaluating the service quality as perceived by the bank customers [11-13]. It is also used in various other sectors to assess the customers' satisfaction with service quality [14-17]. In this method, questionnaires are engaged in order to gauge customers' expectations and perceptions. The SERVQUAL method consists of two main parts:

i. Customers' hope from the service to be received is measured. Prospects are analyzed with respect to the service to be acquired in the individual domain irrespective of the providing firm. ii. Post-service opinions of the client regarding the service are evaluated. Questions are identical to first part, but the firm's name is mentioned. Likert-type scale that ranges from "totally agree" to "totally disagree" is engaged for assessment. Both parts have five service feature assessment scope as Tangibles, Reliability, Responsiveness, Assurance and Empathy, which are spread into 22 items of questionnaire [5]. The various items used in five different dimensions in this study are given in table 1. The Gap or SERVQUAL score is the disparity amid Perception and Expectation (P-E) score given by the bank customer (respondent) for varied scopes of service quality.

Table 1 Questionnaire Item for Five Dimensions of SERVQUAL [5]

\begin{tabular}{|l|l|}
\hline \multicolumn{2}{|c|}{ Items for Tangibles Dimension } \\
\hline 1 & Equipments used are Modern \\
\hline 2 & Attractive Material Facilities \\
\hline 3 & Tidy Employees \\
\hline 4 & Attractive pamphlets and brochures \\
\hline \multicolumn{2}{|c|}{ Items for Reliability Dimension } \\
\hline 5 & Prompt service without delay \\
\hline 6 & Active Interest in clients quandary \\
\hline 7 & Accurate service delivery from the initiation \\
\hline 8 & Apt delivery as promised \\
\hline 9 & Fault free proceedings \\
\hline \multicolumn{2}{|c|}{ Items for Responsiveness Dimension } \\
\hline 10 & Employees provide correct service timing \\
\hline 11 & Punctual Employees \\
\hline 12 & Employees are eager to help clintes \\
\hline 13 & Clints requests are immediately considered \\
\hline \multicolumn{2}{|c|}{ Items for Assurance Dimension } \\
\hline 14 & Staff behavior inspire assurance in clientele. \\
\hline 15 & patrons experience security in dealings. \\
\hline 16 & Staff is polite with clients. \\
\hline 17 & $\begin{array}{l}\text { Staff is pre-equipped with information to respond to } \\
\text { clientele query }\end{array}$ \\
\hline \multicolumn{2}{|c|}{ Itempathy Dimension } \\
\hline 18 & Every Client get individual consideration. \\
\hline 19 & Expedient operating hours vis-à-vis patrons. \\
\hline 20 & Staff provides personalized attention to clients. \\
\hline 21 & Bank always looks for client's best interests \\
\hline 22 & Staff is aware of explicit requirements of customers. \\
\hline
\end{tabular}

\section{Results and Discussions}

The study employs the SERVQUAL instrument for assessing the service quality of diverse private and public banks operating in the state of Rajasthan, India. Respondents were randomly selected using social media networking and emails. More than 300 people were approached, out of which 108 
eventually responded with full questionnaire for expectations and perceptions. The SERVQUAL instrument has an inherent higher mortality rate as many of the respondents dropped off after filling up the initial questionnaire on Expectations.

The SERVQUAL instrument used in present study is identical to the one originally proposed by Parasuraman et al. [5]. There are 44 questions in total, with 22 questions each in the Expectations and Perception part. A 5-point Likert-scaled is used to quantify the responses. Microsoft Excel [18] and IBM SPSS [19] are employed for statistical data processing in our study.

The expectation part of Instrument questionnaire is divided into two parts. The first part asks about the demographic profile of respondents and second part has 22 items to assess their expectations vis-àvis banking sector. Perception part of the instrument questionnaire has only one part, where the respondents' opinion of the service offered by the bank was analyzed using 22 items. The 22 items in the both the questionnaire were designed to assess the respondents views on five factors i.e. Tangibles, Reliability, Responsiveness, Assurance and Empathy, as mentioned in table 1.

The demographic and associated information items in first part of questionnaire consisted of name, gender, age, marital status, education, ownership of smart phone, credit card, PayTm/BHIM [20, 21] and use of online banking and preferred payment mode (cash or cashless). As shown in table 2, 72 percent of respondents were female, while 55 percent of respondents were of age greater than 35 years. About 67 percent respondents had an educational degree of graduate level or higher.

Table 2 Educational Background of Respondents

\begin{tabular}{|c|l|r|}
\hline Factor & Category & Percentage \\
\hline \multirow{2}{*}{ Gender } & Male & $\mathbf{2 7 . 7 8 \%}$ \\
\cline { 2 - 3 } & Female & $\mathbf{7 2 . 2 2} \%$ \\
\hline \multirow{2}{*}{ Age Group } & Below 35 & $\mathbf{4 4 . 4 4 \%}$ \\
\cline { 2 - 3 } & Aboove 35 & $55.56 \%$ \\
\hline \multirow{2}{*}{ Education } & Non Graduate & $\mathbf{3 3 . 3 3 \%}$ \\
\cline { 2 - 3 } & Graduate & $66.67 \%$ \\
\hline
\end{tabular}

Table 3 gives the descriptive of the five dimensions analyzed in the study. The maximum, minimum, mean, standard deviation and skewness of the data is shown from the responses of expectations (Exp) and perceptions (Per) questionnaires. Low mean perception score of 3.59, 3.62 and 3.65 were found for the reliability, responsiveness and empathy dimensions, respectively.
This shows that there may be some concerning issues faced by the respondents vis-à-vis banks consistency, dependability, trustworthiness and credibility. Further, lower perception score for responsiveness may have been caused by sullied receptiveness, less openness, lower awareness and delayed or indifferent reaction by bank. A low empathy score may be a reflection of lower understanding of customers' expectations, apart from the lower sympathy and compassion shown by bank executives.

Table 3 Descriptive Statistics of Dimensions

\begin{tabular}{|c|c|c|c|c|c|c|}
\hline \multirow{2}{*}{ Dimension } & Exp/Per & Mean & Max & Min & STDV & Skew \\
\hline \multirow{2}{*}{ Tangible } & Exp & 3.96 & 5 & 1 & 0.83 & -0.93 \\
\cline { 2 - 7 } & Per & 3.81 & 5 & 2 & 0.75 & -0.59 \\
\hline \multirow{2}{*}{ Reliability } & Exp & 4.00 & 5 & 2 & 0.86 & -0.68 \\
\cline { 2 - 7 } & Per & 3.59 & 5 & 2 & 0.87 & -0.43 \\
\hline \multirow{2}{*}{ Responsiveness } & Exp & 3.83 & 5 & 2 & 0.87 & -0.49 \\
\cline { 2 - 7 } & Per & 3.62 & 5 & 2 & 0.83 & -0.31 \\
\hline \multirow{2}{*}{ Assurance } & Exp & 4.12 & 5 & 2 & 0.70 & -0.65 \\
\cline { 2 - 7 } & Per & 3.97 & 5 & 2 & 0.75 & -0.34 \\
\hline \multirow{2}{*}{ Empathy } & Exp & 3.67 & 5 & 1 & 0.98 & -0.58 \\
\cline { 2 - 7 } & Per & 3.65 & 5 & 2 & 0.86 & -0.22 \\
\hline
\end{tabular}

A high perception mean score on tangibles and assurance dimension may give an idea about overall good infrastructure of Indian urban banks and helping, supportive and comforting nature of service providers in banks. However, the mean scores of perception dimensions in individual capacity may not give the correct and complete picture of bank's service quality. As an example, the dimension of empathy has a low mean score of 3.65 in customers' perception, but it also had a very low mean score in the customers' expectation (3.67). So, a customer may not be that much disappointed or feels cheated on the aspect of empathy as the expectations were already quite low. On the other hand, reliability dimension has a very high expectation mean score of 4.0, whereas its perception score is quite low in comparison (3.59 only). Therefore, the clientele may feel far more cheated and uncomfortable on the aspect of reliability, in comparison to the element of empathy, even when both the proportions have almost identical low scores in customers' perception. To understand and point out this aspect of customer's experience, the SERVQUAL scores (gaps) are computed and shown in table 4, and the corresponding gaps in expectations and perceptions scores is shown in figure 1. SERVQUAL scores compare the deportment of the bank vis-a-vis each 
extent of service quality. More negative scores point to bank being not doing well in fulfilling customers' hopes and sensitivity, while positive value demonstrates the fact that the firm surpasses its customers' expectations.

Table 4 SERVQUAL Analysis

\begin{tabular}{|c|c|c|}
\hline Dimension & $\begin{array}{c}\text { SERVQUAL } \\
\text { Score }\end{array}$ & $\begin{array}{c}\text { Percentage } \\
\text { of Customer } \\
\text { Stisfaction }\end{array}$ \\
\hline Tangible & -0.150 & 0.962 \\
\hline Reliability & -0.415 & 0.896 \\
\hline Responsiveness & -0.208 & 0.946 \\
\hline Assurance & -0.146 & 0.965 \\
\hline Empathy & -0.026 & 0.993 \\
\hline
\end{tabular}

Figure 1 SERVQUAL Scores

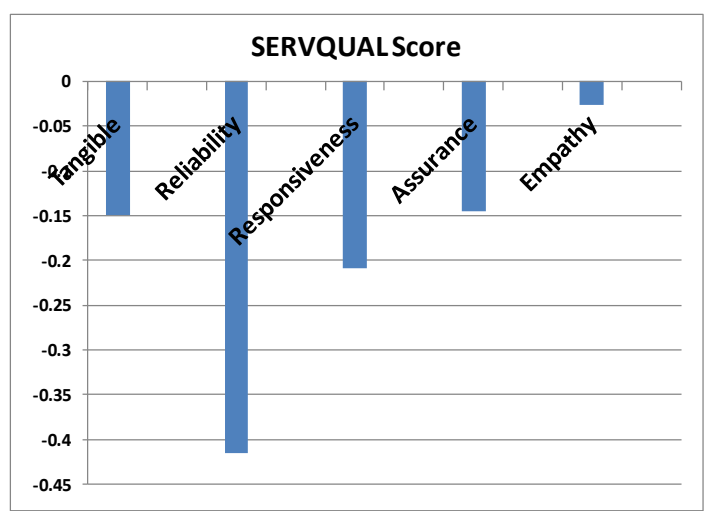

From the table 4 and figure 1, it can be seen that Indian urban banks do not exceed the customers' expectations. All the SERVQUAL scores are in negatives, with varying degrees. Smallest SERVQUAL score of -0.026is found for the dimension of empathy and largest gap of -0.41 is found for the dimension of reliability. This could be interpreted as customers being most satisfied with the understanding and compassion shown by the bank executives while most dissatisfied with the lack of dependability and constancy of the banks. This could be also supported by the plot of percentage of customer satisfaction, as shown in figure 2 .

Empathy is found to be the most satisfactory aspect with 99 percent customers' expectations met by banks, while reliability is found to be the most deficient aspect of Indian urban banks with about 90 percent of customers' expectation fulfilled. The various reasons for low ranking of reliability dimension needs to be investigated, as it could downgrade the overall efforts of other service quality positive effects. One of the reasons for the same could well be associated with the recent negative news on very high quantity of NonPerforming Asset (NPA) in Indian banking sector $[22,23]$.

Figure 2 Percentage Customer Satisfactions

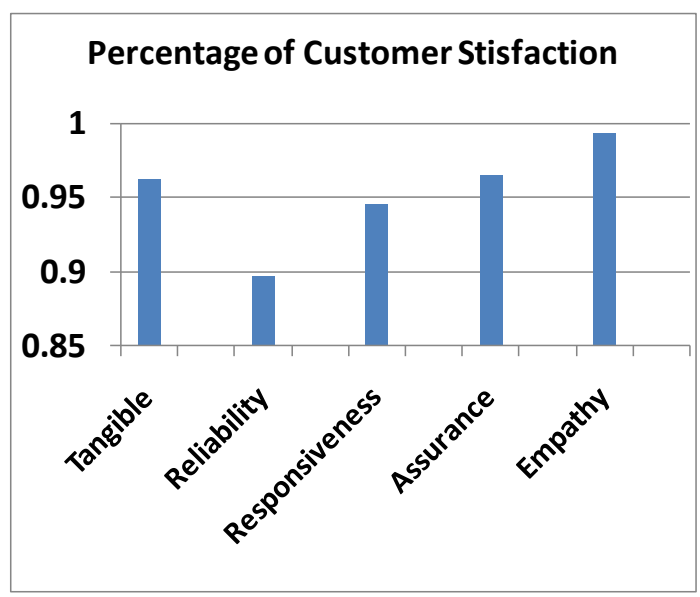

Correlation analysis was further done on various gaps (for respective dimensions) affecting the average SERVQUAL score as shown in table 5. The data brings out the respective correlations between the various service quality scopes and service quality score (client satisfaction score).

Table 5 Correlation Analysis

\begin{tabular}{|c|c|c|c|c|c|}
\hline \multicolumn{7}{|c|}{ Correlations } \\
\hline & Tang & Rel & Resp & Assu & Emp \\
\hline $\begin{array}{c}\text { Average } \\
\text { ServQual } \\
\text { Score }\end{array}$ & 0.55 & 0.78 & 0.88 & 0.78 & 0.86 \\
\hline
\end{tabular}

It can be seen that the responsiveness influence the client satisfaction mainly (0.88) and tangibles has the lowest correlation with average SERVQUAL score $(0.55)$. A positive correlation between SERVQUAL score and all the five service quality dimensions suggests that if we improve on any of the five aspects of service quality, the customer satisfaction also perks up. Data also suggests that the upgrading done on the responsiveness will affect the customer approval rank far more than other dimensions of service quality.

\section{Conclusion}

In the era of cutthroat competition in banking sector, a bank would always be investigating for its customers' outlook and perception regarding banks 
service quality. A continuous feedback from the customers would enable the bank to perform its services better and always remain ahead of the competition. SERVQUAL is an instrument with a proven track record in this domain, arguably. The present study employs the SERVQUAL method and found a positive correlation between the five scopes of service quality assessment and the SERVQUAL score (customers' satisfaction).

Further, the results show that a client would first and foremost expect "assurance" from the bank staff (highest expectation score of 4.12). On second rank, reliability of a bank is expected by the customers. It seems that a customer expect its bank staff to be reassuring and true to its words. The staff must speak the truth about various schemes and related substance and should guarantee the execution of the same within the promised time. Further, customers would like its banking transactions to be safe, secure and confidential and therefore the reliability of the bank rank very high in customers' expectations.

In the present study of urban banking sector of Rajasthan, India, it was found that overall customer satisfaction is quite high and about 95 percent of their overall expectations are met by the bank. This is a very high satisfaction score and could be due to the reason that PMJDY scheme has revolutionized the Indian banking sector. Almost 400 million new customers have joined the Indian banking sector after the launch of PMJDY in 2014, and amazing feats were achieved by this financial inclusion scheme such as 18 million accounts opening in one week [24]. The scheme is still going on and Indian banking sector has apparently managed to upgrade itself for the task.

Further, the study found a very small gap score for the dimension of empathy and largest gap of -for the dimension of reliability. This could be interpreted as customers being most satisfied with the understanding and compassion shown by the bank executives while most dissatisfied with the lack of dependability and constancy of the banks. Negative news on various present NPAs in Indian banking sector may well explain this customers' lack of trust.

An interesting aspect of the study is high mean expectation score and high mean perception score for tangibles. A high mean perception score on tangibles shows that investments are coming for Indian banking sector and PMJDY may have benefitted the overall banking sector in more than one ways. The correlation of tangible dimension with average SERVQUAL score is lower than other factors (.55), but a bank could never neglect the effects of physical infrastructure and properties for enhancing banks customer satisfaction. At present, more and more customers are switching to online banking and are far less dependent on physically interacting with banks. Nonetheless, the high expectation score for tangibles shows that a customer expect its bank to look smart. Pecuniary organizations need to devise professional looking commercial workplace that promotes a tech-savvy culture. That effectively means that the cramped up cubicle cells needs to be replaced with brilliant, vibrant, appealing offices that highlight "enjoyable" and "teamwork" among the staff and customers alike. An additional advantage of a vibrant office space is attraction to prospective talented staff for the banks. As banks are switching more and more towards digital domain, the conventional banking staff would be replaced by data analysts and software professionals. The expectations of these specialist professionals would be higher and they would also prefer to work in an office environment which looks modern and vibrant. Therefore, an effortless handy service, orderly and uncluttered office space of banks and tidy and smart bank staff would positively affect the customers' perception about the bank even before the consumption of services.

In conclusion, it may be said that in the present era of very high customer exposure and subsequently changing preferences, banks have a very demanding task to achieve maximum customer satisfaction. The undertaking by bank staff becomes more challenging due to the somewhat unique fact that banking operations and allied procedures may not be publicly known and the associated jargon may intimidate a new customer. Therefore, it would be very important for any bank to have an understanding and well aware staff with a pleasing and understanding personality. A bank would sustain its growth and customers if it follows the expectations of its customers closely and swiftly address any issues regarding the same. The present study outlines the fact that Indian urban banks may be ticking all the boxes in that format and may well be having an interesting and promising future. The wide-ranging conclusions of the present study can be briefed as:

- For sustained positive growth, Indian banks need to invest enough time and money in improving the five dimensions of service quality i.e. Tangibles, Reliability, Responsiveness, Assurance and Empathy.

- Indian banks are upgrading at a fast pace to satisfy their clientele.

- Indian banks may still have to work on the NPA and other security issues to win customers' trust. 


\section{References:}

[1] PMJDY 2020 (Pradhanmantri Jan Dhan Yojna) https://pmjdy.gov.in/

[2] Tara N, Addressing financial exclusion in France and India: A review of Strategies and Institutions, FMSH-WP-2017, fevrier 2017.

[3] Okunlola FA, Alatise MA, Ogunniyi OR, Adejumo MO, Financial Inclusion for Sustainable Economy: Empirical Evidence from Nigeria. WSEAS Transactions on Business and Economics, Vol 17, 2020, pp. 205-214.

[4] Shetty N, Pinto P, Financial exclusion:concept, causes \& consequences A Tridimensional literature analysis. Pezzottaite Journals, Vol.4, No.1, 2015, pp. 79-96.

[5] Parasuraman A, Zeithaml VA, Berry LL, SERVQUAL: A Multiple-Item Scale for Measuring Consumer Perceptions of Service Quality. Journal of Retailing, Vol. 64, No. 1, 1988, pp. 12-40.

[6] Xiaohua Duan, Systematic Risk Measurement Based on CoVaR Model, International Journal of Circuits, Systems and Signal Processing, pp. 243-250, Volume 13, 2019.

[7] Ribaj A, Ilollari O. Asymmetric Information versus Banks' Costumer Trust, Albania case linked with SEE countries. WSEAS Transactions on Business and Economics, Vol 16, 2019, pp. 288-297.

[8] Ribaj A, Ilollari O, Scalera F. The Unethical Banking Costs Distrust of Bank Customers (Albania Case as a Model for SEE Countries). WSEAS Transactions on Business and Economics, Vol 16, 2019, pp. 582-592.

[9] Alsaawy Y, Alkhodre A, Benaida M, Khan RA. A Comparative Study of Multiple Regression Analysis and Back Propagation Neural Network Approaches for Predicting Financial Strength of Banks: An Indian Perspective. WSEAS Transactions on Business and Economics, Vol 17, 2020, pp. 627-637.

[10] Mawardi W, Mahfudz M, Laksana RD, Shaferi I. Competition and Financial Effects between Islamic and Conventional Banking. WSEAS Transactions on Business and Economics, Vol 17, 2020, pp. 101-111.

[11] Ilyas A, Nasir H, Malik MR, Mirza UE, Munir S, Sajid A. Assessing the service quality of Bank using SERVQUAL model. Interdisciplinary Journal Of Contemporary Research In Business, Vol 4, No. 11, 2013, pp. 390-400.
[12] Lau MM, Cheung R, Lam AYC, Chu YT. Measuring Service Quality in the Banking Industry: A Hong Kong Based Study. Contemporary Management Research, Vol 9, No. 3, 2013, pp. 263-282.

[13] Kakouris AP, Finos PK. Applying SERVQUAL to the Banking Industry. EASTWEST Journal of ECONOMICS AND BUSINESS, Vol XIX, No. 2, 2016, pp. 57-71.

[14] Mosimanegape P, Jaiyeoba O, Iwu CG, Mahama CC. Examining the relationship between service quality and customer satisfaction in the public service. The case of Botswana. WSEAS Transactions on Business and Economics, Vol 17, 2020, pp. 579-593.

[15] Pena MM, Silva EMSD, Tronchin DMR, Melleiro MM. The use of the quality model of Parasuraman, Zeithaml and Berry in health services. Revista da Escola de Enfermagem da USP, Vol 47, No. 5, 2013, pp. 1227-1232.

[16] Stimc H, Simic ML. Competitiveness In Higher Education: A Need For Marketing Orientation And Service Quality. Recent Issues in Economic Development, Vol 5, No. 2, 2012, pp. 23-34.

[17] Wong KL, Ong SF, Kuek TY. Constructing a Survey Questionnaire to Collect Data on Service Quality of Business Academics. European Journal of Social Sciences, Vol 29, No. 2, 2012, pp. 209-221.

[18] Microsoft Excel 2020. https://www.microsoft.com/en-in/microsoft365/excel

[19] IBM SPSS 2020. https://www.ibm.com/inen/analytics/spss-statistics-software

[20] PayTm 2020. https://paytm.com/

[21] BHIM UPI 2020. https://www.bhimupi.org.in/

[22] Singh A. Indian banks sitting on NPA cluster bomb ready to explode after March 31. Available at: https://www.deccanherald.com/business/busine ss-news/indian-banks-sitting-on-npa-clusterbomb-ready-to-explode-after-march-31796181.html

[23] Ganatra, RM. Indian Banks' High NPAs And Abysmally Low Recovery: Revamp Or Perish. Available at http://www.businessworld.in/article/IndianBanks-High-NPAs-and-Abysmally-LowRecovery-Revamp-or-Perish/05-06-2020$\underline{194309 /}$

[24] PMJDY Guinness World Record. https://pmjdy.gov.in/guinness-world-record

\section{Creative Commons Attribution License 4.0 (Attribution 4.0 International, CC BY 4.0)}

This article is published under the terms of the Creative Commons Attribution License 4.0

https://creativecommons.org/licenses/by/4.0/deed.en_US 